\title{
Studies on neotropical Protoneuridae. 15. Amazoneura gen. nov. with description of $A$. juruaensis sp. nov. (Odonata, Zygoptera)
}

\author{
Angelo B. M. Machado \\ Departamento de Zoologia, Instituto de Ciências Biológicas, Universidade Federal de Minas Gerais. Caixa Postal 486, \\ 31270-901 Belo Horizonte, Minas Gerais, Brasil.
}

\begin{abstract}
The genus Amazoneura is erected to contain A. ephippigera (Selys, 1886), A. westfalli (Machado, 2001) and A. juruaensis sp. nov. The new genus is close to Forcepsioneura Lencioni, 1999 but differs from it mainly by the poorly-developed postero-lateral tubercles of the medium prothoracic lobe, by the dark colour of the metepimerum and of the rear of the head. A. juruaensis sp. nov. (holotype male, Acre, Brazil) differs from the other two species of the genus mainly by the structure of the superior anal appendages.

KEY WORDS. Brazil, new genus, new species, Protoneuridae.
\end{abstract}

RESUMO. Criou-se o gênero Amazoneura para as espécies A. ephippigera (Selys, 1886), A. westfalli (Machado, 2001) e A. juruaensis sp. nov. O novo gênero é próximo de Forcepsioneura Lencioni, 1999 mas difere dele principalmente por ter o tubérculo postero-lateral do lobo médio do protórax pouco desenvolvido e pela cor escura do metepimero e da parte posterior da cabeça. A. juruaensis sp. nov. (holotipo macho, Acre, Brasil) difere das outras duas espécies do gênero principalmente pela estrutura dos apêndices anais superiores.

PALAVRAS CHAVE. Brasil, Protoneuridae, nova espécie, novo gênero.

Machado $(2000,2001)$ divided the known species of Forcepsioneura Lencioni, 1999 in two groups, the sancta and the ephippigera species group. The sancta group contains $F$. sancta (Selys,1886), F. itatiaiae (Santos, 1970), F. garrisoni (Lencioni, 1999) and F. haerteli (Machado, 2001) all from the Atlantic Forest of Brazil. The ephippigera group contains F. ephippigera (Selys, 1886) and F. westfalli (Machado, 2001) from the Amazonian Forest. The discovery of a third species of the ephippigera group makes it convenient to erect a new genus for the three species it contains. We describe now Amazoneura gen. nov. and the new species $A$. juruaensis.

\section{Amazoneura gen. nov.}

Generotype. Amazoneura westfalli (Machado, 2001) by present designation.

Etymology. From the Amazon, an allusion to the fact that the three species of the genus were found in the Amazon region.

Description. Protoneuridae of medium size, abdomen long and slender. General coloration dark with metallic reflections, the dark metepimeral area ventrally confluent with that of the opposite side behind the hind trochanter. Rear of the head black. Apex of the penis with two filaments. Superior anal appendages forcipated each one with a short and stout ventral branch, and a process directed ventrally and medially.
Inferior appendages absent. Prothorax with postero-lateral tubercles scarcely visible or absent. Anal vein absent. CUP terminating between the vein descending from the subnode and that descending from the second postnodal. IR3 arising at the subnodus or slightly distal to it and usually separated from R $4+5$ by a small crossvein. First antenodal costal space longer than the second, equal or slightly longer than the third.

Remarks. Amazoneura belongs to the group of New World Protoneuridae with the anal vein absent and no inferior appendages. To this group belongs the genera Forcepsioneura, Phasmoneura Williamson, 1916, Psaironeura Williamson, 1915 and Roppaneura Santos, 1966. The latter genus stands isolated from the other ones by its yellow colour, by having CUP ending distal to the vein descending from the second postnodal and by having the third antenodal costal space twice longer than the second and the third. Phasmoneura is also quite different from the other genera of the group mainly by the absence of filaments in the penis apex. Amazoneura differs from Psaironeura by its predominantly black colour (red in Psaironeura), larger stature and by having CUP ending distal to the vein descending from the subnodes (at or before this vein in Psaironeura). No doubt the closer genus to Amazoneura is Forcepsioneura to which belonged westfalli and ephippigera, species now transfered to Amazoneura. The generic position of ephippigera has been controversial. Since its description by SeLYS 
(1886) under Protoneura, the species has been placed in Epipleoneura (Williamson 1915, Cowley 1941, SCHMidT 1942, RaCENIS 1960), Phasmoneura (MACHADO 1985) and more recently in Forcepcioneura (LENCIONI 1999). I think the erection of a new genus for ephippigera, together with westfalli and juruaensis, settles the question. The new genus can be separated from Forcepsioneura by having the tubercle of the postero-lateral corner of the median lobe poorly-developed or absent (Fig. 1), the rear of the head black (pale in Forcepsioneura), the second antenodal space equal or longer than the third (shorter in Forcepsioneura) and the metepimeral black area ventrally confluent with that of the opposite side behind the hind trochanter (Fig. 3). As far as I know this character is unique among the Protoneuridae.

Ecological considerations. In Ecuador and Peru, DAIGLE (2000) reported A. ephippigera flying with Metaleptobasis moufrayi (Daigle, 2000) and Psaironeura tenuissima (Selys, 1886) close to the surface or over quiet pools in shaded forests, swamps, and sllugish streams. A note in an envelope containing a couple of $A$. westfalli states that they were collected at the edge of a ravine in a hunting trail. Another note in the envelope of the holotype of $A$. juruaensis states it was collected in a stream within forest. The finding of mud attached to the ovipositor and terminal abdominal segments of a female of $A$. westfalli was taken as evidence that it lays their eggs in muddy substracts (MACHADO 2001). This behaviour might well occur in A. juruaensis and A. ephippigera.

\section{Amazoneura juruaensis sp. nov. Figs 1-4}

Male. Head: labium yellowish. Genae yellowish brown. Labrum dark metallic green. Base of mandible and anteclypeus brown. Postclypeus and frons dark metallic green. Rear of the head black. Prothorax: dorsally dark metallic green, laterally dark. Posterior lobe (Fig. 1) slightly narrower than the median one, with the margin convex. Tubercle of the postero-lateral corner of the median lobe absent (Fig. 1). Pterothorax (Fig. 23): mesopleurum dark metallic green, darker on the mesepimerum. Metapleurum laterally dark, except for a subtrapezoidal yellow area on the supero-posterior part of the metepimerum (Fig. 2). The dark metepimeral area is ventrally confluent with that of the opposite side on the anterior third of the pectus, behind the hind trochanters (Fig. 3). Posterior $2 / 3$ of the pectus yellow (Fig. 3). Legs yellow except for the tarsi which are brown and for a brown band on the posterior parts of the femorae. Wings hyaline. Pterostigma brown surrounded by a yellow line, occupying one cell, its costal side slightly smaller than the radial one, the inner side oblique and the outer side convex. Venation: postnodals in fore wings 1314 ; in hind wings 13 . R3 in fore wings originating at the $6^{\text {th }}$ postnodal; in hind wing at the $4^{\text {th }}$; IR2 in fore wings originating at the $9^{\text {th }}$ posnodal; in hind wings at the $6^{\text {th }}$. CUP in fore wings terminating at one fourth of the distance between the vein descending from the subnodus and that descending from the first postnodal; in hind wings terminating in the middle of this distance. Arculus in both wings coinciding with the second antenodal. $\mathrm{CuA}$ in fore wings situated slightly beyond the middle of the distance between the first and the second antenodal; in hind wings in the middle. IR3 in both wings arising slightly distal to the subnodus and separated from R4+5 by a small crossvein. First antenodal costal space slightly longer than the second, the second space slightly longer than the third. Abdomen: segment 1 yellow with a metallic green dorsal area on its distal half. Segment 2 dark metallic green with a lateral yellow spot. Segments 3-7 brown dorsally. Distal part of 6-8 metallic green dorsally. Segment 9 dark and slightly pruinescent. Segments 3-6 with a basal and a subapical yellow spot. Segment 7 with only the basal yellow spot Segments 1-9 yellowish ventrally; segment 10 metallic green. Superior anal appendages black longer than segment 10 , very slender and only slightly directed upward (Fig. 4), in dorsal view strongly forcipated. Each appendage bears at its base a poorly developed ventral branch (Fig. 4). Ventro-medial process without teeth, not visible in lateral view (Fig. 4). Inferior appendages absent (Fig, 4). Terminal segment of the penis with two filaments.

Measurements $(\mathrm{mm})$. Abdomen with appendages 35.6. Length of fore and hind wings 21.6. Maximum width of the fore wings 3.6, of hind wings 3.5. Pterostigma 0.6. Length of the antenodal costal spaces in both wings 2.4, 2.0, 1.9 .

Material. Holotype male, BraziL, Acre: Mancio Lima (in a strem within the forest), VI-1996, Dionisio leg. Holotype deposited in A.B.M. Machado collection, Belo Horizonte, Minas Gerais. The abdominal segments 9-10 with the appendages were accidentally lost after being described. Fortunatelly, before the accident, a free-hand (Fig. 4) sketchs had been made.

Etymology. An allusion to the bassin of the Juruá river where the species was collected.

Remarks. Amazoneura juruaensis sp. nov. can be easily separated from the other two species of the genus by the characters given in table I. The main difference is the poorly developed ventral branch of the superior anal appendage that is only slightly directed upwards. As written on the envelope by the collector, the specimen was collected in a stream within the forest.

\section{ACKNOWLEDGEMENTS}

I am grateful to Myrian Morato Duarte for the drawing of this paper.

\section{REFERENCES}

Cowley, J. 1941. A new species of Protoneura from Peru and a review of the group of Protoneura tenuis Selys (Odonata, Protoneuridae). Transactions of the Royal Entomological Society of London 91: 145-173. 


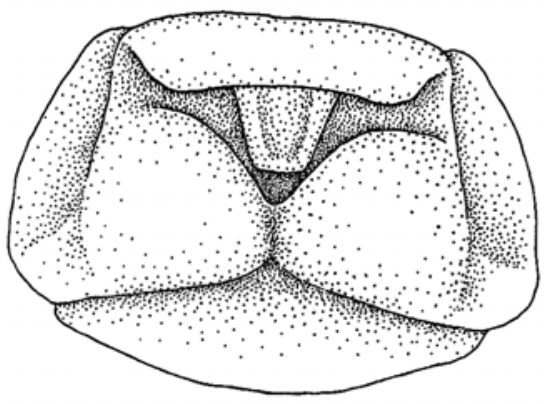

1

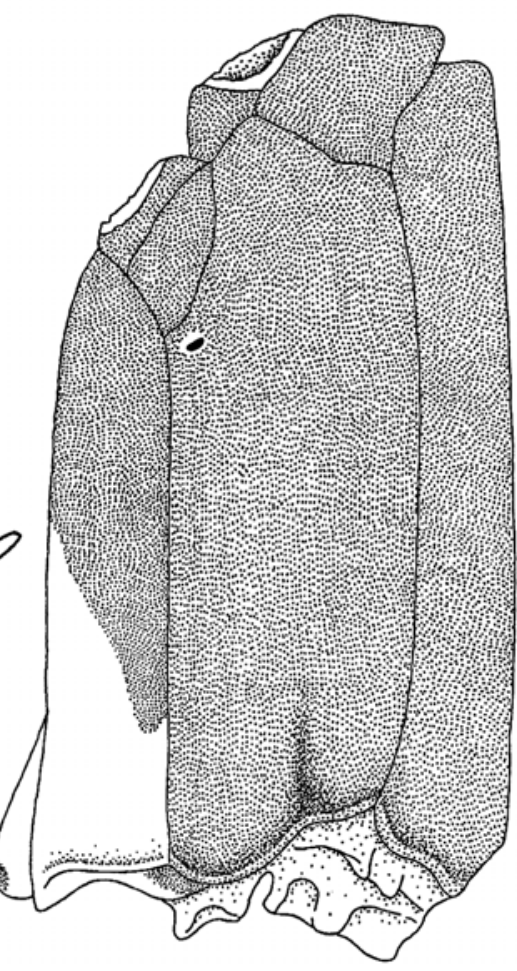

2

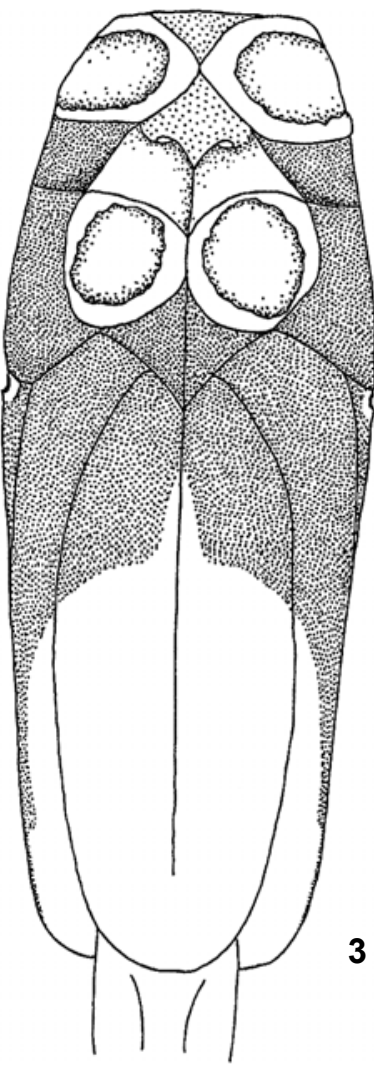

Figures 1-4. Amazoneura juruaensis, sp. nov.: (1) prothorax in dorsal view, camara-lucida drawing; (2-3) color pattern of the pterothorax in lateral (2) and ventral (3) views, both camara-lucida drawing; (4) appendage in lateral view, based in a free-hand sketch.

Table I. Characters separating the males of the three species of Amazoneura.

\begin{tabular}{|c|c|c|c|}
\hline Character & A. juruaensis & A. ephippigera & A. westfalli \\
\hline Superior appendages in lateral view & $\begin{array}{l}\text { Not strongly directed } \\
\text { upwards }\end{array}$ & Strongly direct upwards & Strongly direct upwards \\
\hline $\begin{array}{l}\text { Apex of ventro-medial process of the } \\
\text { superior appendages }\end{array}$ & $\begin{array}{l}\text { Without teeth, not visible } \\
\text { in lateral view }\end{array}$ & $\begin{array}{l}\text { With two minute teeth, visible } \\
\text { in lateral view }\end{array}$ & $\begin{array}{l}\text { Without teeth. Not visible } \\
\text { in lateral view }\end{array}$ \\
\hline Postero-lateral corner of the median lobe & With no tubercle & $\begin{array}{l}\text { With a poorly-developed } \\
\text { tubercle }\end{array}$ & $\begin{array}{l}\text { With a poorly-developed } \\
\text { tubercle }\end{array}$ \\
\hline Ventral branch of superior appendages & Poorly-developed & Well-developed & Well-developed \\
\hline Pruinescence in mature males & $\begin{array}{l}\text { Present on abdominal } \\
\text { segment } 9\end{array}$ & $\begin{array}{l}\text { Present on the prothorax and } \\
\text { pterothorax }\end{array}$ & $\begin{array}{l}\text { Present on abdominal } \\
\text { segment } 9\end{array}$ \\
\hline
\end{tabular}

DAIGLE, J.J. 2000. Metaleptobasis mauffrayi spec. nov. from Ecuador and Peru (Zygoptera: Coenagrionidae). Odonatologica, Bilthoven, 29 (4): 325-328.

Lencioni, F.A.A. 1999. The genus Phasmoneura, with description of Forcepsioneura. gen.nov. and two new species (Zygoptera: Protoneuridae). Odonatologica, Bilthoven, 28 (2): 127137.
Machado, A.B.M. 1985. Studies on neotropical Protoneuridae. 5. Redescription of the types of Phasmoneura ephippigera (Selys, 1886) (Zygoptera). Odonatologica, Bilthoven, 14 (4): 363-368.

2000. Studies on neotropical protoneuridae.10. Forcepsioneura lucia sp. n. from the Parque Estadual Rola Minas Gerais, Brasil. (Odonata, Zygoptera). Boletim do

Revista Brasileira de Zoologia 21 (2): 333-336, junho 2004 
Museu de Biologia Mello Leitão (N. Ser.), Santa Teresa, 11/11: 127-134.

. 2001. Studies on neotropical protoneuridae. 11. Two new species Forcepsioneura Lencioni (Odonata, Zygoptera) with a key to the male of the genus. Revista Brasileira de Zoologia, Curitiba, 18 (3): 845-854.

Racenis, J. 1960. Cuatro especes del genero Epipleoneura (Odonata: Protoneuridae). Acta Biologia Venezuelica, Caracas, 3: 25-42.

Schmidt, E. 1942. Odonata, nebst Bemerküngen über die Anomisma und Chalcopteryx des Amazonas Gebietes, p.
225-276. In: E. Tiтsснак (Ed.). Beiträge 3 zur Fauna Perus nach der Ausbeute der Hamburger Südperu Expedition 1936. Jena, G. Fischer, vol. 2.

Selys-Longchamps, M.E. De. 1886. Revision du synopsis des Agrionines. Prèmiere partie. Les légions Pseudostigma Podagrion - Platycnemis et Protoneura. Mémoires couronnés et autres Mémmoires publiés par l'Académie Royal de Belgique, Bruxeles, 38:1-233.

Wluiamson, E.B. 1915. Notes on neotropical dragonflies or Odonata. Proceeding of the United States National Museum, Washington, 48: 601-638.

Received in 29.VIII.2003; accepted in 03.VI.2004.

Revista Brasileira de Zoologia 21 (2): 333-336, junho 2004 